\title{
Immobilization of bacteriophage in wound-dressing nanostructure
}

\author{
Frederico Nogueira ${ }^{\mathrm{a}, \mathrm{b}}$, Natia Karumidze ${ }^{\mathrm{c}}$, Ia Kusradze ${ }^{\mathrm{c}}$, Marina Goderdzishvilic ${ }^{\mathrm{c}}$, Pilar Teixeira ${ }^{\mathrm{d}}$, Isabel C. Gouveia ${ }^{\mathrm{b}, *}$ \\ ${ }^{a}$ CICS-UBI-Health Sciences Research Centre, University of Beira Interior, Portugal \\ ${ }^{\mathrm{b}}$ FibEnTech - Fiber Materials and Environmental Technologies, University of Beira Interior, Portugal \\ ${ }^{c}$ G. Eliava Institute of Bacteriophages, Microbiology and Virology, Tbilisi, Georgia \\ ${ }^{\mathrm{d}}$ Institute for Biotechnology and Bioengineering (IBB), Portugal
}

\section{A R T I C L E I N F O}

\section{Article history:}

Received 25 March 2017

Accepted 9 August 2017

Available online $\mathrm{xxx}$

Key words:

Bacteriophages

Antimicrobial agents

Surface immobilization

Electrospinning

Pseudomonas aeruginosa

\begin{abstract}
A B S T R A C T
Opportunistic bacteria that cause life-threatening infections are still a central problem associated with a healthcare setting. Bacteriophage capsid immobilization on nanostructured polymers maximizes its tail exposure and looks promising in applications toward skin-infections as alternative to antibiotics standardly used. The main goal of this work was to investigate the covalent immobilization of vB Pae Kakheti25 bacteriophage capsid on polycaprolactone (PCL) nanofibers (non-woven textile), as a potential effective antimicrobial, laundry resistant and non-toxic dressing for biomedical use. Surface analyses showed that the immobilization of vB Pae Kakheti25 bacteriophage capsid on PCL nanofibres oriented bacteriophage tails to interact with bacteria. Furthermore, antimicrobial assays showed a very effective 6 log bacterial reduction, which was equivalent to $99.9999 \%$, after immediate and 2 hours of contact, even following 25 washing cycles (due to covalent bond). The activity of PCL-vB_Pae_Kakheti25 against $P$. aeruginos $a$ was immediate and its reduction was complete.
\end{abstract}

(C) 2017

The skin of patients with inflammatory skin-diseases alongside with chronic or burn wounds and exit-sites of catheters is particularly susceptible to infection by different microorganisms. Opportunistic pathogens are the cause of skin diseases, infections, and the inability of chronic wounds to heal. ${ }^{1-4}$ They are capable of producing virulence factors, including enzymes that promote tissue invasion and extracellular polymers, which form the biofilm that contributes to the perpetuation of skin inflammation, even in normal-appearing skin. Fortunately, the majority of our resident skin microorganisms are non-pathogenic and many of these contribute to maintaining health. ${ }^{1}$ Accordingly, skin-disease/injury management demands an integrated approach aimed not only at diminishing infection but also at regulating the skin microbiome.

$P$. aeruginosa is the most common infectious agent among Pseudomonas spp. As a versatile and opportunistic microorganism it can colonize the skin, soft tissue, gastrointestinal tract, armpits, eye and ear. ${ }^{6-8} P$. aeruginosa is the agent responsible for the most common infections under hospital settings, through catheter and ventilator contaminations leading to nosocomial infections, such as pneumonia, urinary tract and wound burn infections, as well as bacteremia, especially in patients with diabetes or immunodeficiency. ${ }^{8}$ The major

\footnotetext{
Acknowledgments: The authors acknowledge the Fundação para a Ciência e Tecnologia (FCT) for the PhD grant SFRH/BD/91444/2012 and Programa Operacional Capital Humano $(\mathrm{POCH})$ and European Union for co-funding the work.

* Corresponding author at: FibEnTech R\&D Fiber Materials and Environmental Technologies, University of Beira Interior, 6201-001 Covilhã, Portugal. Email address: igouveia@ubi.pt (I.C. Gouveia)
}

concerns about the control of nosocomial infections vary from the problems of drug safety associated with a high human toxicity, the long-term and large scale application of broad-spectrum antibiotic drugs, to the increased resistance to conventional therapies. These infections tend to chronicity and may fail to be treated with almost any combination of antibiotics, showing mortalities up to $61 \%{ }^{9}$ The combination therapy to fight $P$. aeruginosa infections is very difficult to achieve, due to the compromised immune system of the majority of infected patients, and the intrinsic resistance of microorganisms to various antibiotics. ${ }^{10}$

Recent research has been conducted on the three groups of naturally occurring antimicrobials as novel alternatives to antibiotics: bacteriophages, bacterial cell wall hydrolases (BCWHs), and antimicrobial peptides (AMPs). ${ }^{11}$ Among them, bacteriophages are the most highly specific toward both Gram-positive and Gram-negative bacteria and they are also highly efficient and relatively cost-effective. In contrast, AMPs have a broad-spectrum against bacteria and fungus, low level of induced resistance, but may cause toxicity at high doses in order to be efficient, and are more costly to produce. ${ }^{11} \mathrm{BCWH}$ has limitations toward Gram-negative bacteria, as a result of the presence of the outer membrane, and important Gram-positive pathogens like $S$. aureus are already resistant to lysozymes. To overcome the changing tide of nosocomial diseases and increasing reports of microorganism-acquired resistances, recently the United States, Canada and European countries have started to take a close interest in bacteriophage-based therapies, ${ }^{12,13}$ in which they act without mechanism-based host toxicity.

The bacteriophage vB_Pae_Kakheti25 has a potent activity against $P$. aeruginosa and appears as an alternative approach to con- 
ventional treatments, especially as an antimicrobial agent for dressing. It is representative of siphoviral family, has dsDNA as its genome, icosahedral capsid, and long non-contractile tail. vB_Pae_Kakheti25 undergoes a lytic cycle through which it self-replicates and lyses a broad range of $P$. aeruginosa strains in order to spread copies of itself.

Polycaprolactone (PCL), an hydrophobic polyester, can be explored as a substrate for skin regeneration due to its high elasticity and slow biodegradability. ${ }^{14,15}$ Furthermore, it is not broken down by enzymes and microorganisms. ${ }^{14}$ These features seem worthy of dressing applications. $^{16}$

The textile and medical industries continue to look for eco-friendly processes that may replace the currently used toxic textile chemicals and the use of antibiotics, respectively. ${ }^{17-19}$ The demand for medicinal products alternative to antibiotics has increased considerably and our proposed application seems promising due to its versatility, low content of impurities, antistatic properties and good mechanical properties. Furthermore, as PCL is unfavorable for the development of microorganisms, its shelf life and users' health status are also ensured.

In this work, in order to eliminate the growth of $P$. aeruginosa, PCL electrospun nanofibers were threaded and then vBPae Kakheti25 bacteriophages were covalently immobilized by their capsid via acid-amine reactions, forming amide linkages. The effect of anti- $P$. aeruginosa activity of PCL-vB_Pae_Kakheti25 dressing was evaluated under various parameters, so as to produce appropriate applications toward skin-infections, and aiming to further highlight the potential of phage as the "antibiotic" of the millennium by minimizing bacterial resistance and preserving skin-microbiome.

\section{Methods}

Materials

Polycaprolactone nanostructure (PCL), average Mn 45,000 (Sigma), was functionalized in a vB_Pae-Kakheti25 bacteriophage solution. PA25 (DSM 25642) clinical isolates of Pseudomonas aeruginosa from the Eliava culture collection were used for isolation and subsequent growth of vB_Pae-Kakheti25 bacteriophages. P. aeruginosa was grown on Brain Heart Infusion (BHI) agar and then on Brain Heart Infusion (BHI) broth (Sigma) at $30^{\circ} \mathrm{C}$ and in shaker at $200 \mathrm{rpm}$.

Methods

\section{Electrospinning}

Nanofibers were produced by NanoSpider (Elmarco s.r.o. Liberec, Czech Republic). PCL 15\% (w/v) was dissolved in a mixture of absolute ethanol/chloroform $(65: 35 \mathrm{vol} . \%)$ to prepare a homogeneous solution. Different ratios of ethanol/chloroform solvents were used in order to optimize the final nanostructure. The final concentration of PCL and ratio of solvents were set according to the homogeneity of resulting nanofibers, their easy-detachment from polypropylene-coated collecting electrode and tensile strength. The electrospinning process was done under the following experimental conditions: $\mathrm{RH} \approx 65 \%$, temperature $\approx 25^{\circ} \mathrm{C}$, electric voltage $\approx 80 \mathrm{kV}$, distance between electrodes $=8.98 \mathrm{~cm}$, and electrode $\operatorname{spin}=7 \mathrm{r} / \mathrm{min}(44 \mathrm{~Hz})$. Figure 1 shows the representative images of these nanofibers.

\section{Tensile strength assays}

Tensile strength of electrospun PCL was evaluated with resistance-to-rupture assays. These assays were performed in a Dy-

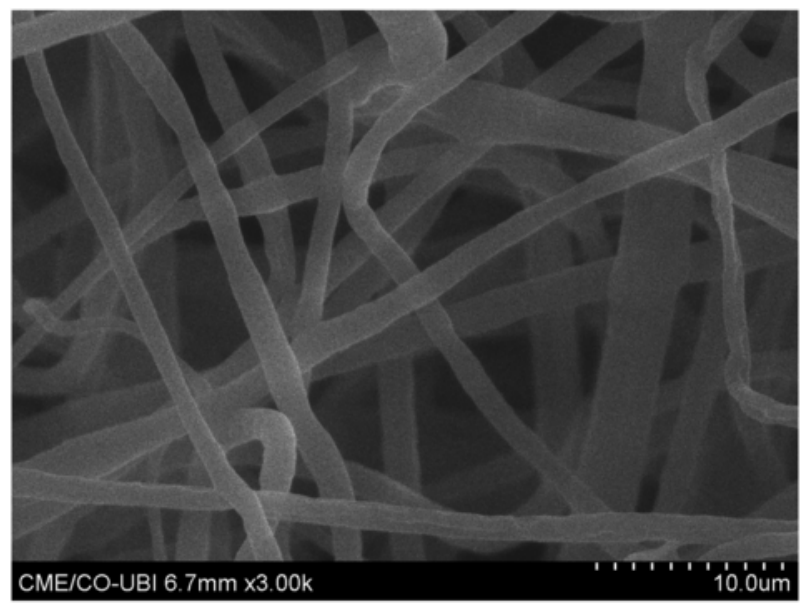

Figure 1. Polycaprolactone (PCL) $15 \%(\mathrm{w} / \mathrm{V})$ electrospun fibers. Tendency of forming layers of curlicues. $3000 \times$ magnification.

namometer (Thwing-Albert Instrument Co.) according to Standard EN ISO 2062 , at $20 \pm 2{ }^{\circ} \mathrm{C}$, under $60 \%$ relative humidity. Samples were strip-cut $1 \times 5 \mathrm{~cm}$, with an average thickness of $50.33 \mu \mathrm{m}$, grammage of $18.6 \mathrm{~g} / \mathrm{m}^{2}$, and placed between dynamometer tweezers. A defined pre-tension was set in the beginning, and the test ended with the rupture of samples. Seven replicates were used.

\section{Protein structure modeling - I-TASSER method}

The sequence of amino acids (UniProtKB) of the Major capsid protein referred to as H6WTZ9-1 and Major tail tube protein referred to as H6WU05-1 of vB_Pae-Kakheti25 bacteriophage were the following, respectively: MALSDLAVYSEYAYSAFSETLRQQVDLFNTATGGAIMLQSAAHQGDFSDVAFFAKVTGGLVRRRNAYGSGTVAEKVLKHLVDTSVKVAAGTPPVRLDPGQFRWIQQNPEVAGAAMGQQLAVDTMADMLNVGLGSVYSALSQVSDVVYDATANTDAADKLPTWNNLNNGQAKFGDQSSQIAAWIMHSTPMHKLYGSNLTNGERLFTYGTVNVVRDPFGKLLVMTDSPNLFAAGTPNVYHILGLVPGGVLIGQNNDFDANEETKNGDENIIRTYQAEWSYNIGVKGFAWDKANGGKSPTDAALFTSTNWDKYATSHKDLAGVVVKTN;

MVCEIAKIDSNITGLAFAEEECLKQLPTTPVWYGLEPNSYSDFGGELSTVARAPIDPSRQNKKGTITDLDASGGFNADFTKTNLARILQGFFFADARELPSTQPLNGASVALTGVTAIDSTYAAASGLGVFGADMLVYATGFANAANNGLKTVVSATAAGVVVAETLIDETPPAGAKLECVGRQLAAADANIAVTGNVVSLIVTAGDFTTMPELFAGRWVFVGGDATANRFANNVGYARIKSVAAKALVFDDVTWQAVNETGTGKSIRLFVGTVIKNEKTPALIKRRSYQIERTLGEGLNGTQCEYLEGAVPNEFTLNVPQADKLNADLSFVACDNTYRSGDPGDEQKAGTRVPAPGEDAYNTSSDVYRIKMAVHDAASSNPAALFGYVSEANVSINNNVTPNKAVGVLGAFDTSAGNFEVGGSITAYFTTVAAVKAVRANADVGLSVISAAKNAGFVFDIPLLGLGGGRLNVEKDAPITVPLEPAGAENANGYTMLYEVFSYLPNLAMPD.

For the simulation, these sequences were threaded from Protein Data Bank library, where multiple template alignments were generated. Then, the continuous fragments were excised, reassembed, clustered and this full process was repeated. I-TASSER used the most significant templates with the lowest energy. ${ }^{20-23}$ The predicted structures were analyzed for polarity and ligand binding sites. 


\section{Ninhydrin}

In order to ascertain the presence of free amines on vB Pae-Kakheti25 capsid, i.e. the estimation of the quantity of $\mathrm{vB}_{-}^{-}$Pae-Kakheti25 that PCL nanofibers were able to crosslink, ninhydrin assays were done. Ninhydrin hydrates with amino groups, producing purpurous Ruhemann's cromophore $(\lambda \max 570 \mathrm{~nm})$. This colorimetric assay was performed after drawing a calibration with known concentrations of L-cysteine. Each sample was added $2 \mathrm{~mL}$ of $10^{8} \mathrm{vB}$ Pae-Kakheti25/ml and $1 \mathrm{ml}$ of $8 \%$ Ninhydrin (acetone). $\mathrm{ddH}_{2} \mathrm{O}$ was used for controls. Test tubes were placed in water bath at $100{ }^{\circ} \mathrm{C}$ for 10 minutes and then cooled down to room temperature before they were read at $570 \mathrm{~nm}$.

\section{PCL substrate preparation}

\section{Nanofiber functionalization}

After being formed with electrospinning, non-woven nanofibrous PCL was washed for 4 hours with distilled water, at $40{ }^{\circ} \mathrm{C}, 110 \mathrm{rpm}$, and dried afterwards at $30{ }^{\circ} \mathrm{C}$ until used, in order to remove any surface residues and impurities. Samples were stored in the desiccator until use. For the activation of the surface, samples were submersed in acidic solution ( $\mathrm{pH} 5.5$ ) for 60 minutes at $40{ }^{\circ} \mathrm{C}$. Soon afterwards they were washed in deionized water. After the activation process, these were submitted to the functionalization process by exhaustion with vB_Pae-Kakheti25 bacteriophages via their amine compounds. For the exhaustion functionalization process, a MOI of 0.1 vB_Pae-Kakheti25 bacteriophages was prepared. Each sample was immersed in a bioactive solution at a liquor ratio of 1:50 in the beakers of the Ahiba datacolor dyeing machine and submitted to $40{ }^{\circ} \mathrm{C}$ for 60 minutes. Finally, samples were washed in deionized water and stored in the fridge.

\section{Washing cycles assay - resistance to laundry}

Laundry operations were performed before any characterization, so as to assess PCL-vB Pae-Kakheti25 covalent bonding resistance. The methodology was adapted from the international standard EN ISO 105-C06:2010, as follows: (i) washing in $\mathrm{ddH}_{2} \mathrm{O}$ throughout 5 and 25 washing cycles, at $40{ }^{\circ} \mathrm{C}$ for 30 minutes each, and (ii) washing in a $4 \mathrm{~g} / \mathrm{L}$ solution of AATCC 1993 Standard Reference Detergent WOB throughout 5 and 25 washing cycles at $40{ }^{\circ} \mathrm{C}$ during 30 minutes each.

\section{Fourier transform infrared spectroscopy (FT-IR)}

The chemical arrangement of PCL nanostructure and PCL-vB_Pae-Kakheti25 was analyzed after three rinses (no washing cycles), 5 and 25 washing cycles with Thermo-Nicolet is 10 spectrophotometer. Samples were scanned 64 times, with a spatial frequency resolution of $4 \mathrm{~cm}^{-1}$.

\section{Antimicrobial activity assessment}

PCL-vB_Pae-Kakheti25 substrates were tested according to Japanese Industrial Standard JIS L 1902:2002, designed to test all fabric samples tailored to healthcare industry. Pseudomonas aeruginosa was the selected agent once it is responsible for the most common infections under hospital settings, with mortalities up to $61 \%{ }^{9}$ Briefly, the inoculum of $P$. aeruginosa was adjusted to $1-5 \times 10^{6}$ bacteria/ $\mathrm{mL}$, of which $200 \mu \mathrm{l}$ were inoculated on $0.4 \mathrm{~g}$ PCL-vB_Pae-Kakheti25 circle samples. Following an incubation of 2 hours, antimicrobial activity was calculated in order to determine bacterial growth inhibition (\% of Inhibition) at 2 hours:

$$
\text { \% Inhibition }=\frac{C-A}{C} \times 100
$$

Where $\mathrm{C}$ is the average value of Colony Forming Units (CFU) of controls, and A represents the average value of CFU of PCL-vB_Pae-Kakheti25.

\section{Growth kinetics of infected bacteria}

One-step growth experiments were performed in order to evaluate the latent phase and burst size of vB_Pae-Kakheti25, according to. ${ }^{24}$

\section{Transmission electron microscopy (TEM)}

The vB Pae-Kakheti25 life cycle together with its host $P$. aeruginosa was monitored by TEM (HITACHI HT7700) at 0, 15, 30, 60 and 120 minutes. Furthermore, the bonding frequency of vB_Pae-Kakheti25 on PCL nanofibers was also visualized. Samples were stained with $2 \%$ uranyl acetate during 5 minutes, and framed on a thin bar copper web covered with formvar. Various magnitudes were used at an accelerating voltage of $80 \mathrm{KV}$.

\section{Cytotoxicity Activity Assay}

The cytotoxicity of PCL-vB_Pae-Kakheti25 was performed according to, ${ }^{25}$ in two different assays: perspiration extract assay and direct contact assay. In the first assay, 2 g of PCL-vB_Pae-Kakheti25 samples were immersed for $24 \mathrm{~h}$ at $37^{\circ} \mathrm{C}$ in PBS. The resulting perspiration extract was filtered $(0.2 \mathrm{um})$ and was then blended with cells, at concentrations of $4.4,6.6,9.9,14.8,22.2$, and $33.3 \%$. The second assay, direct contact assay, consisted in placing at the center of each well a PCL-vB_Pae-Kakheti25 sample disc that covered $1 / 10$ of its area. Fibroblasts 3 T3 were used to seed each well at a concentration of $2 \times 10^{4}$ cells/well. In the final part of both assays incubation was conducted at $37{ }^{\circ} \mathrm{C}$ for $24 \mathrm{~h}$, under a humidified atmosphere containing $5 \% \mathrm{CO}_{2}$. MTS viability assay was performed. Solvent, positive and negative controls were included.

\section{Statistical analysis}

Statistics software SPSS 21.0 was used to calculate one-way ANOVA and Tukey post-hoc tests for establishing multiple comparisons between all samples. P-values below 0.05 were considered statistically significant.

\section{Results}

\section{Sample characterization}

\section{Electrospun fibers}

Nanofibers were produced with an average thickness of 1.57 $\mathrm{nm} \pm 0.26$ Figure 1 .

\section{Tensile strength assays}

Tensile tests evaluated the mechanical properties of developed electrospun samples. Elastic modulus was observed for electrospun PCL nanofibers (10.64 Mpa \pm 2.99$)$ with an elongation of $13.95 \% \pm 2.43$. Results between samples were not significantly different, which means it demonstrated reproducibility.

\section{Protein structure modeling}

The predicted secondary structure of Major capsid protein was arranged in globular domains, forming hexamers, comprised of alpha and beta structures. Major tube protein was arranged in $\beta$-helix, ac- 
cording to the I-TASSER algorithm. ${ }^{16-19}$ Furthermore, the bioinformatics modeling of these structures were generated using the SPICKER program based on pair-wise structure similarity. C-scores varied from -1.72 to -1.38 . In Figure $2, A$ and $B$, it is presented the structure predictions of Major capsid protein and Major tube protein, respectively. Non-polar side chains remained uncharged at physiological $\mathrm{pH}$ and were incapable of participating in hydrogen bonding. On the other hand, in Major tube protein, seven polar leucine-15,47,88,112,178,385, and 464 were identified. Furthermore four polar asparagine191,259,277, and 336 were detected, as well as two polar glutamine-11 and 303. All of them contained an $\alpha$-amino group protonated at $-\mathrm{NH}_{3}{ }^{+}$under biological conditions. These are important for cross-linking to outer sheath proteins around Major tube protein. Furthermore leucine-507, methionine-509, proline-510 and aspartate-511 constitute an acidic terminal region, important to bind and be capped by the spike protein.

The first subunit of the Major capsid protein presents polar lysine-38 and glycine-45. Furthermore it presents an RGD sequence-44,45,46; aspartate-82,98, valine-85, and glycine-90,112 in the second subunit; aspartate-144,148, leucine-132, valine-135, serine-137 in the third subunit; aspartate-157,174, serine-177,186, methionine-184,189, histidine-185 in the fourth subunit; aspartate-224, serine-225, valine-236, glycine-245, glutamate-259, asparagine-263 in the fifth subunit; glycine-284 in the sixth subunit. Under physiological conditions ( $\mathrm{pH} 7.4$ ) lysine, arginine, histidine side chains were positively charged $-\mathrm{NH}_{3}{ }^{+}$and important for covalent bonding to PCL surface.

\section{Ninhydrin}

The free amines on vB Pae-Kakheti25 capsid were quantified with ninhydrin reagent. A calibration curve $\left(\mathrm{r}^{2}=0.99\right)$ was performed with known concentrations of L-cysteine (which contains only one amino group), and finally, the concentration of amines in bacteriophage solution was determined. Each bacteriophage was found to have 2.85 picogram of free amines.
Fourier transform infrared spectroscopy (FT-IR)

The FT-IR spectrum of unmodified nanofilm is shown in Figure $3, A$. This spectrum displays the expected representative peaks of polycaprolactone, namely $\mathrm{C}-\mathrm{H}$, related with $\mathrm{CH}_{2}$ stretching vibrations at $2943 \mathrm{~cm}^{-1}$ and $2865 \mathrm{~cm}^{-1}$, and with carbonyl adsorption at 1721 $\mathrm{cm}^{-1} .26$

The covalent bonds between PCL and vB Pae-Kakheti25 on nanofibers, were also assessed by FT-IR after 5 and 25 washing cycles. IR spectra showed PCL surface with carboxylic acid after its activation at $1712 \mathrm{~cm}^{-1}$, and vB_Pae-Kakheti25 grafted on nanofibers, as denoted by the increase of the peaks owed to covalent bonds formed with PCL surface, namely at $1667 \mathrm{~cm}^{-1}$ and $1541 \mathrm{~cm}^{-1}$, assigned to Amide I and II, respectively, as well as the decrease of free carboxylic acid at $1711 \mathrm{~cm}^{-1}$, as shown in Figure $3, B$ and $C$.

\section{Antimicrobial assays}

\section{Quantitative method (suspension)}

In order to evaluate the antimicrobial effectiveness of PCL-vB Pae-Kakheti25, the adsorption test was performed to quantify the ability of nanofibers functionalized with bacteriophages to prevent bacterial growth Figure 4. The results showed that there were marked reductions in Pseudomonas aeruginosa at T0 h and T2 h. PCL activated nanofibers showed outstanding microbial inhibition, as shown in Figure 4. We could observe that PCL-vB_Pae-Kakheti25 eliminated 6 $\log$ of Pseudomonas aeruginosa at 0 and 2 hours, which was equivalent to $99.9999 \%$ reduction.

After 5 and 25 washing cycles with WOB at $40{ }^{\circ} \mathrm{C}$, the same $6 \log$ elimination of Pseudomonas aeruginosa was observed, either at 0 or at 2-hour. These results proved that covalent bonding between PCL and the bacteriophage capsid was stable and strong enough to resist to several washings.

In order to know whether the samples behaved as bacteriostatic or bactericidal, according to Japanese Industrial Standard JIS L 1902:2002, the bacteriostatic activity result can be not less than 2.0 and bactericidal activity result cannot be less than 0 . Briefly, bacterio-

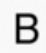

B

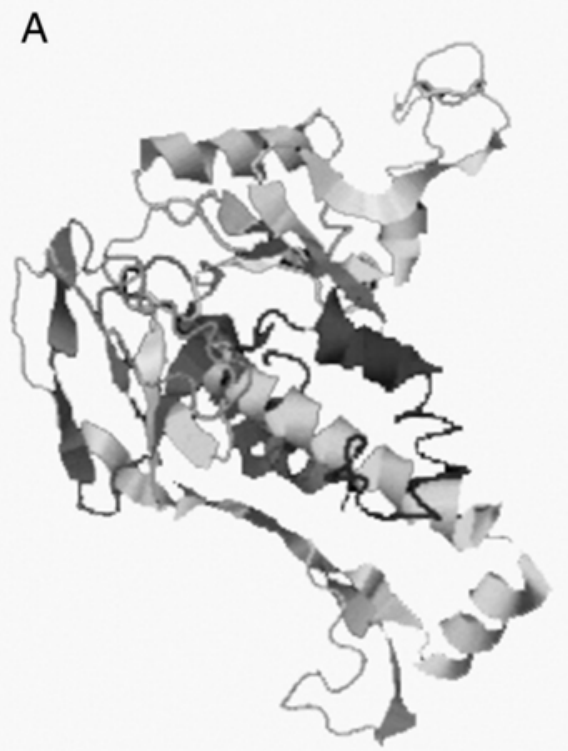

B

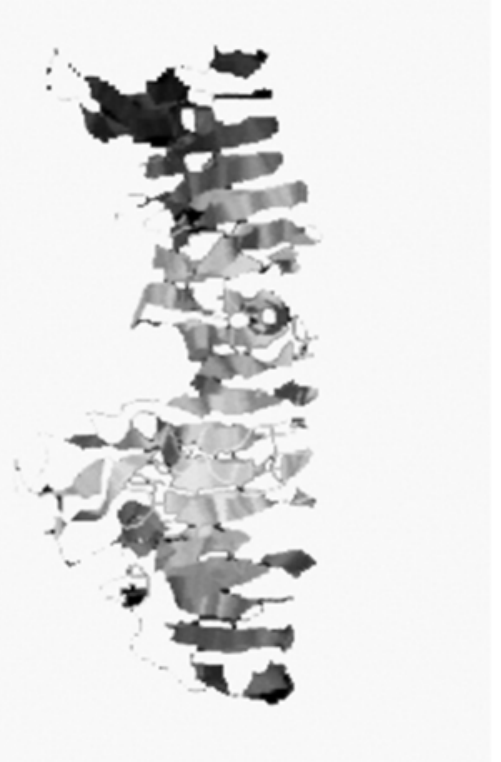

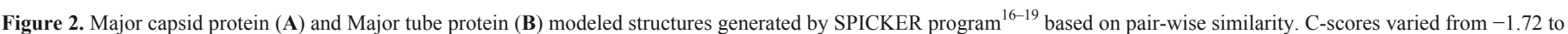
-1.38 . 


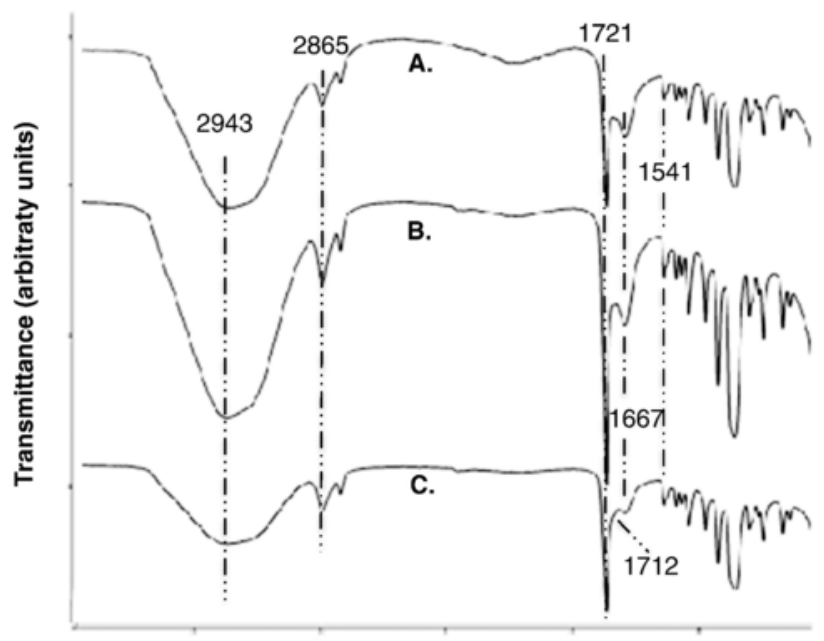

Wavenumber $\left(\mathrm{cm}^{-1}\right)$

Figure 3. IR spectra of unmodified PCL (A) and PCL-vB_Pae_Kakheti25 after (B) 5 washing-cycles and (C) 25 washing-cycles.

static activity $=\log 10$ of the average of bacterial colonies on the control samples at T24 h- $\log 10$ of the average of bacterial colonies on the functionalized samples at $\mathrm{T} 24 \mathrm{~h}$; and bactericidal activity $=\log 10$ of the average number of bacterial colonies on the control samples at $\mathrm{T} 0-\log 10$ of the average of bacterial colonies on the functionalized samples at $\mathrm{T} 24 \mathrm{~h}$.

The calculated values from these equations yielded the following values: after three rinses, bacteriostatic activity was 0.94 and bactericidal activity was 1.63; after 5 washing cycles, bacteriostatic activity was 0 and bactericidal activity was 0.98 ; after 25 washing cycles, bacteriostatic activity was 0 and bactericidal activity was 0 . These results state that PCL-vB_Pae-Kakheti25 has a bactericidal effect after 3 rinses, 5 and 25 washing cycles, which means that the immobilization of vB_Pae-Kakheti25 on PCL lead to death of P. aeruginosa and do not interfere in the development and growth of bacteria.

\section{Growth kinetics of infected bacteria}

This assay aimed to study the growth kinetics of the infected host cells, using a control (uninfected bacteria), at the dressing change temperature of $29.9{ }^{\circ} \mathrm{C}$ Figure 5 .

At this temperature the infected $P$. aeruginosa showed lower absorbance values than those obtained by the non-infected $P$. aerugi- nosa from 20 minutes after the beginning of incubation. This indicated that vB_Pae-Kakheti25 had been using the bacterial machinery for its benefit (latent period). A decrease in bacterial growth rate after 120 minutes were also observed, which indicated the onset of cell lysis phase, resulting from bacteriophage infection.

\section{Transmission electron microscopy (TEM)}

The interaction between vB Pae-Kakheti25 tail and $P$. aeruginosa membrane is shown in Figure $\overline{6}, A$ and $B$. The vB_Pae-Kakheti25 life cycle inside $P$. aeruginosa cells was also monitored at $0,20,30$, and 120 minutes, as shown in Figure 6, C-F. vB Pae-Kakheti25 bacteriophage fiercely degraded $P$. aeruginosa membranes, especially after 20 minutes (Figure 6, D-F). Furthermore, the spacing of the bonding of vB_Pae-Kakheti25 on PCL after 25 washing cycles was also visualized, as shown in Figure 7. The frequency of covalent bonds of vB_Pae-Kakheti25 on PCL nanofibers averaged $118 \mathrm{~nm}$, as shown in Figure 7, $A$.

\section{Tumoral activity assay}

PCL-vB_Pae-Kakheti25 did not show any cytotoxic effect over mouse fibroblast cell line BALB/c 3 T3 Figure 8. Both perspiration extract assay and direct contact assay showed values that did not ranged beyond 30\% from controls. Only an alteration under or over $30 \%$ in comparison with controls would be considered cytotoxic or pro-tumorigenic, respectively. ${ }^{21}$

\section{Discussion}

As part of natural defenses of ecosystem, the mode of action of bacteriophages is very specific and relies on infecting exclusively their host bacteria, leaving the rest of microbiota and human tissues intact. In this investigation, the capsid of the bacteriophage vB_Pae-Kakheti25 was covalently cross-linked to polycaprolactone (PCL) nanofibrous dressing, in order to maximize vB_Pae-Kakheti25 tail exposure, evaluate its stability, and its antimicrobial effect over Pseudomonas aeruginosa bacteria. The electrospun nanofibrous structures offer larger area of contact and a smoother surface, which diminishes roughness and scratching. ${ }^{27}$

A nanofibrous dressing with an average thickness of $1.57 \mathrm{~nm}$ was produced by electrospinning. For the covalent immobilization of bacteriophage capsid onto PCL nanofibers, the first step was the formation of reactive acid groups on PCL, namely ester groups (-COO-) that were hydrolyzed to carboxylic acid groups from ester under acidic solution $(\mathrm{pH}$ 5.5) via the reverse of Fischer esterification.
A

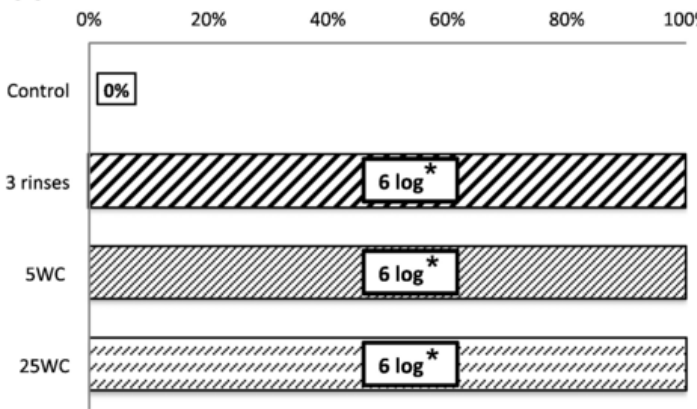

B

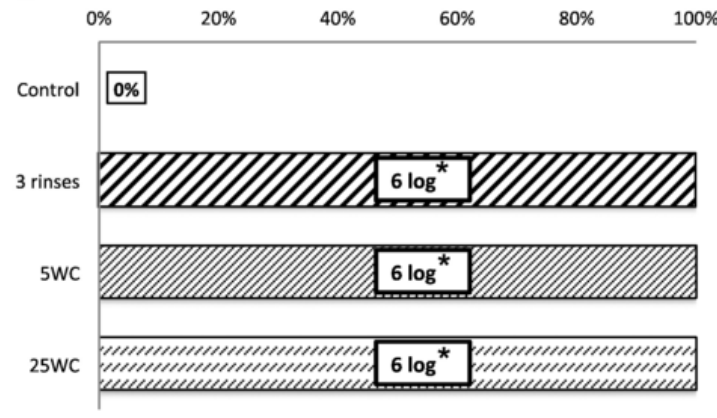

$\square$ Control $\square_{3}$ rinses $\square 5 W C \quad \square_{25 C}$

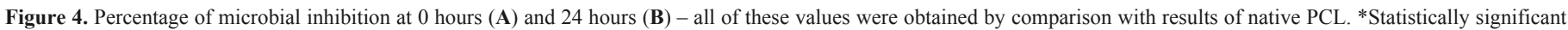
from controls $(p<0.05)$ 


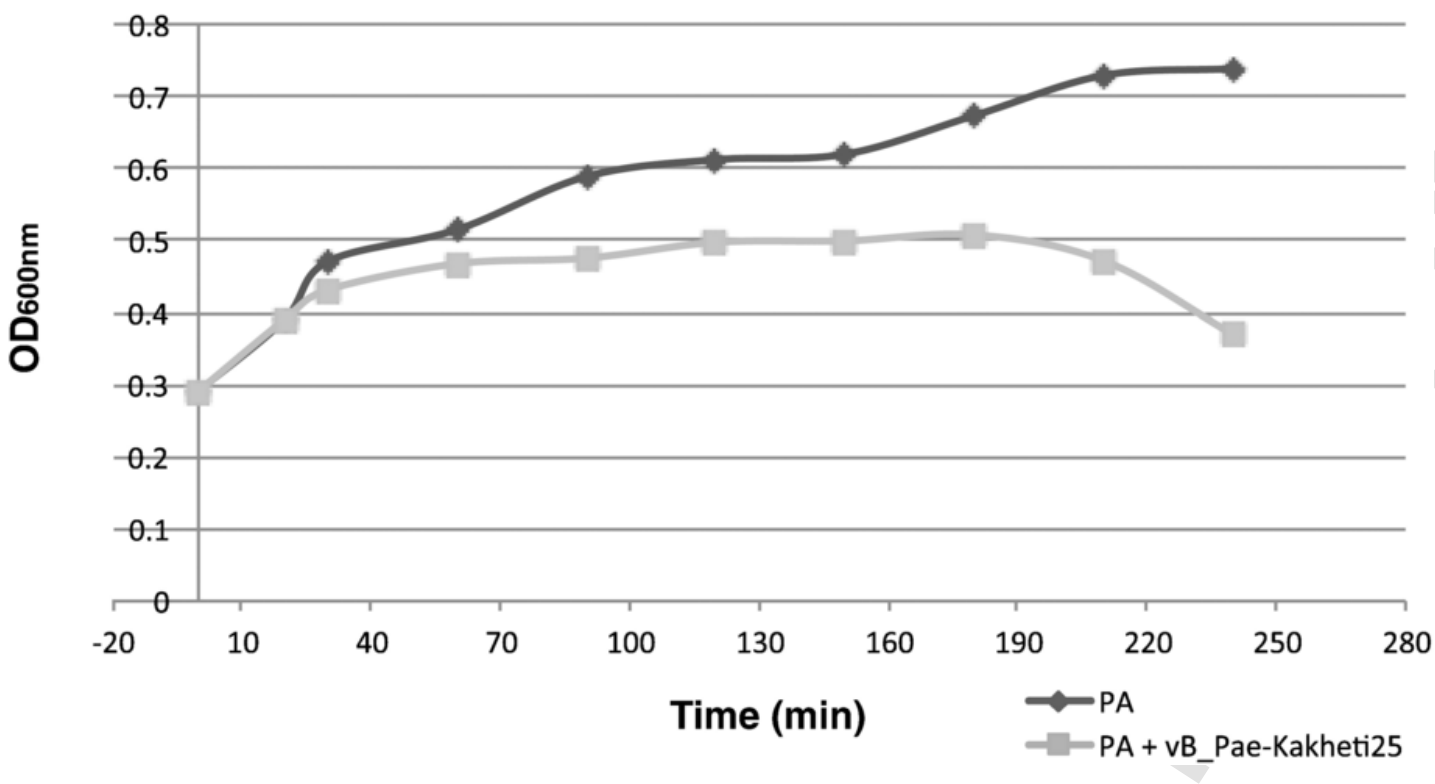

Figure 5. One-step growth kinetics of P. aeruginosa strain and P. aeruginosa infected with the bacteriophage vB_Pae-Kakheti25 at $29.9{ }^{\circ} \mathrm{C}$.
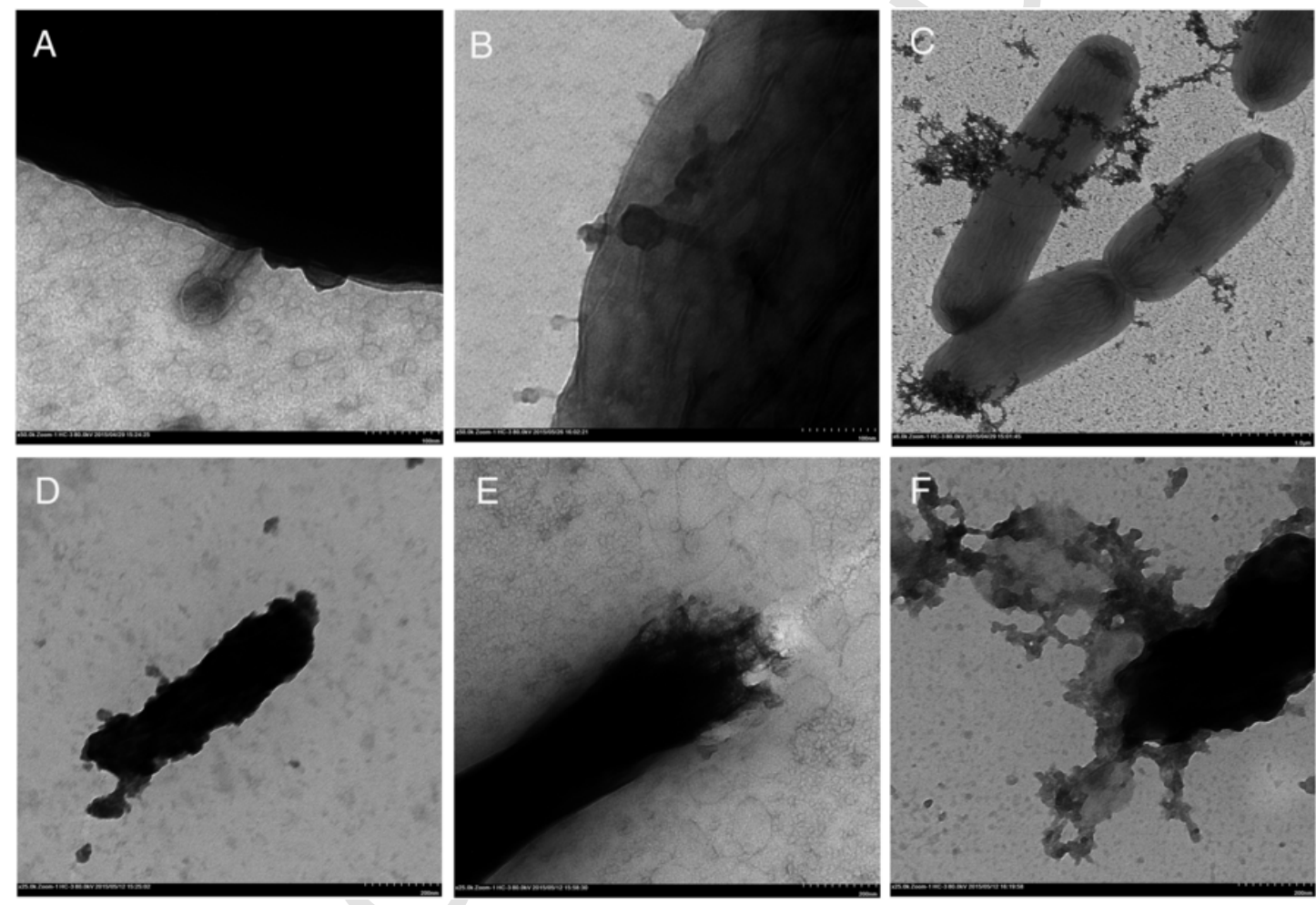

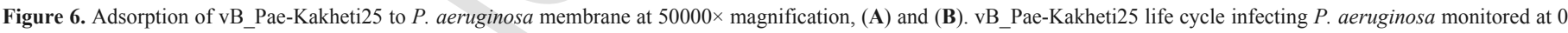
(C), 20 (D), 30 (E), and 120 minutes (F). $6000 \times$ and 25,000 $\times$ magnifications.

Amino groups of vB Pae-Kakheti25 capsid - 2.85 picogram of free amines per bacteriophage - reacted as soon as they contacted the carboxylic acids of PCL, via acid-amine reactions, forming amide linkages. vB Pae-Kakheti25 bacteriophage contains an icosahedral head structure that is composed of many copies of Major capsid protein (UniProtKB) with 325 amino acid length and lysine, arginine, histidine side chains that were positively charged under physiologic $\mathrm{pH}$. Also vB_Pae-Kakheti25 presents a tail that recognizes surface recep- tors of $P$. aeruginosa. Mechanical properties of PCL nanofibers showed high elasticity and were not significantly altered in any treatments in this study, which means PCL structure was not degraded during the experiment.

Fourier Transform Infrared Spectroscopy (FT-IR) and Transmission Electron Microscopy (TEM) provided evidence for the proposed bacteriophage immobilization aligned in a head-to-tail orientation. FT-IR spectra confirmed that bacteriophage capsid was covalently 

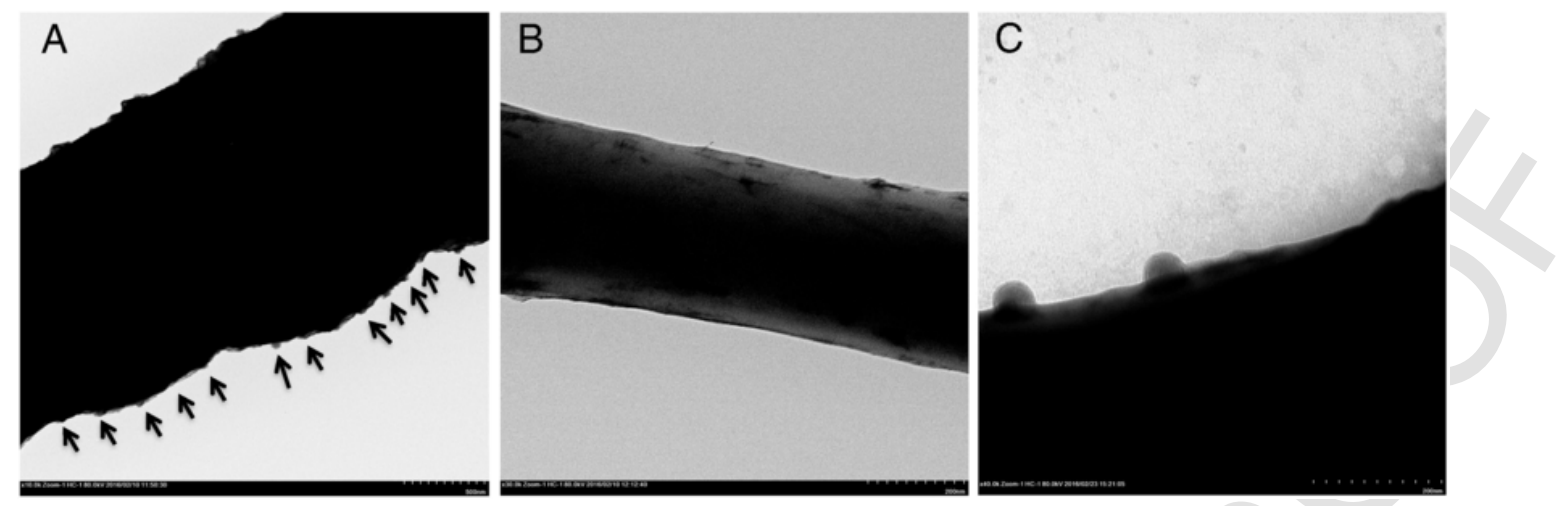

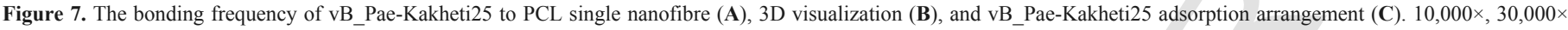
and $40,000 \times$ magnifications.

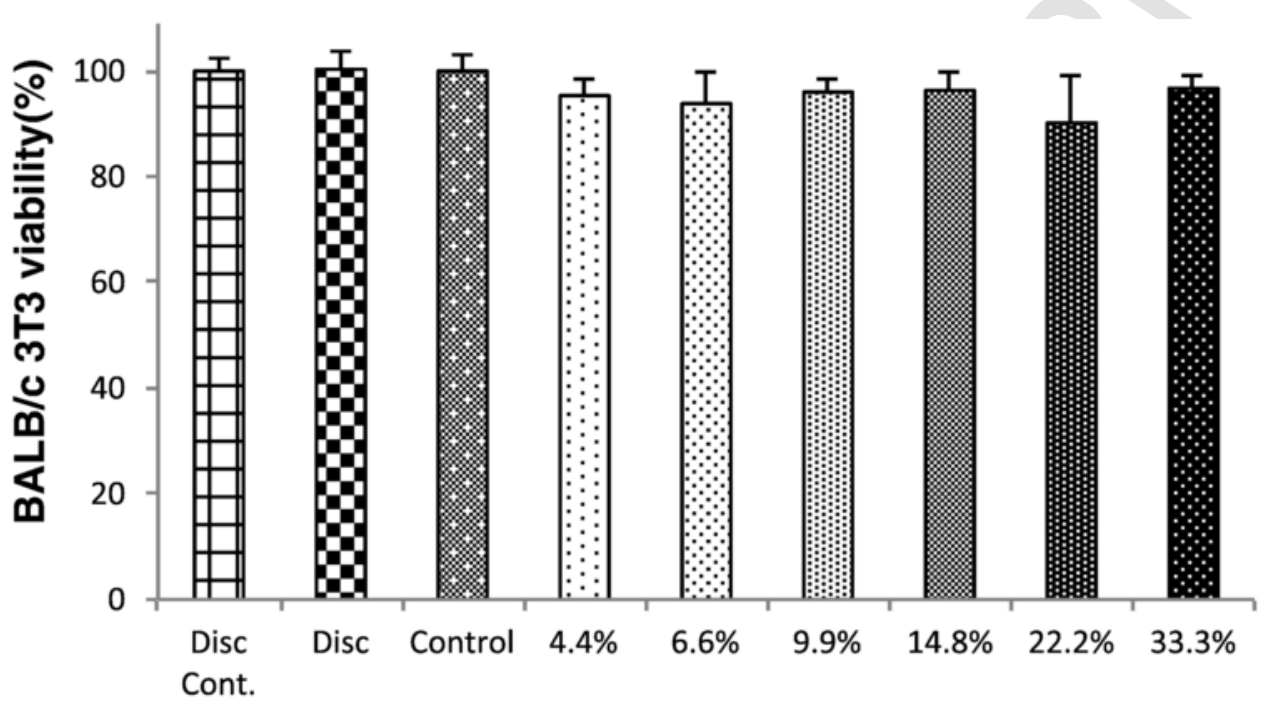

Contact assay

Perspiration extracts

Figure 8. Perspiration extract assay and direct contact assay against mouse fibroblast cell line BALB/c 3 T3.

immobilized on PCL surface, by the comparison of peak height proportions $\left(1667 \mathrm{~cm}^{-1}, 1541 \mathrm{~cm}^{-1}\right.$ and $\left.1711 \mathrm{~cm}^{-1}\right)$ between PCL and PCL grafted with vB Pae-Kakheti25. Furthermore, spectra showed the covalent cross-link between PCL and vB_Pae-Kakheti25 to be multiple washing-resistant -5 and 25 washing cycles - and consequently stable, because the aforementioned peaks height proportions were maintained. In accordance with these previous data, TEM images showed vB_Pae-Kakheti25 immobilized on PCL nanofibers and aligned in a head-to-tail orientation after it had been washed 25 times. Immobilized bacteriophages were also spaced $\approx 118 \mathrm{~nm}$ apart on both sides.

Antimicrobial assays of vB Pae-Kakheti25-bearing PCL showed that it acted as soon as it contacted with $P$. aeruginosa, with antimicrobial reducing rates of $99.9999 \%(6 \log ), p<0.05$. In addition, PCL-vB_Pae-Kakheti25 was identically active after 25 washing cycles, either at immediate contact, or at 2-hour contact. These results were higher than the $5 \log$ reduction observed by Huang et al. for silver-chitosan. ${ }^{28}$ The low natural adhesion of $\mathrm{PCL}^{29}$ due to its hydrophobic character - contact angle of $109.9^{\circ} \pm 5.0^{\circ 29}$ - may also have facilitated the contact of $P$. aeruginosa with the bacteriophage tails. H. Yang and Y. Deng ${ }^{30}$ also showed that a hydrophobic surface reduced adhesion capacity of PCL to bacteria. ${ }^{30}$

Although Karumidze et $a l^{24}$ studied the effect of $\mathrm{vB}_{-}$Pae-Kakheti25 on $P$. aeruginosa, the immobilization of $\mathrm{vB}_{-}^{-}$Pae-Kakheti25 on whichever surface has not been reported yet. Since a vB Pae-Kakheti25 multiplicity of infection of 0.1 led to a general growth inhibition of $P$. aeruginosa in BHI agar plates, ${ }^{24}$ it would be assured that a surface functionalized with the same amount of $\mathrm{vB}$ Pae-Kakheti25 would also kill $P$. aeruginosa, especially due to its maximized tail exposure and the larger area of contact of electrospun nanofibers. On the other hand, when in solution, vB_Pae_Kakheti25 bacteriophages aggregated together by generating bonds between their tails, and consequently decreasing their accessibility to interact with $P$. aeruginosa, as also proposed by Langlet et al. ${ }^{31}$

The growth kinetics was studied at $29.9{ }^{\circ} \mathrm{C}$, which is the temperature of the dressing change procedure. The $P$. aeruginosa was observed to halt its exponential growth as it became infected by vB_Pae-Kakheti25 bacteriophage. This demonstrated that as soon as $\bar{P}$. aeruginosa was infected, $\mathrm{vB}$ Pae-Kakheti25 used its machinery for self-replication, the so-called latent period. The lysis phase began when bacteria started to have a decrease in bacterial growth rate at 
120 minutes, where $P$. aeruginos a mainly undergone the release of recently-formed bacteriophages.

Our samples were adequately tested on mouse fibroblast cell line in order to ascertain whether they were cytotoxic. The perspiration extract of samples showed an average cell growth inhibition of $5.3 \%$ and the direct contact assay showed an average growth enhancement of $0.33 \%$. A variation of growth of more than $30 \%$ in comparison with the controls is regarded as cell-toxic effect. ${ }^{32}$ Therefore, the cytotoxicity assay for PCL-vB_Pae-Kakheti25 showed less than 30\% of cellular viability reduction, making our invention a safe agent for use in contact with skin.

While there are a few commercial antimicrobial applications, they present limitations. Dermasilk ${ }^{\circledR}$ is a silk-based material with Si-QAC (Silane quaternary ammonium compounds) combining the smoothness of silk with the antimicrobial properties. ${ }^{2,33}$ Another example is Padycare ${ }^{\circledR}$ a micromesh polyamide/lycra containing woven silver fil-

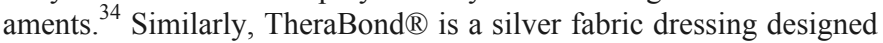
to optimize wound fluid management without compromising the antimicrobial properties. ${ }^{2,3}$ In vitro studies of these garments demonstrated a significant decrease in $P$. aeruginosa. Even though there is no evidence for skin sensitization by bulk silver, a possible systemic absorption of silver particles because of a disrupt skin barrier has to be considered, while Si-QAC is reported to cause bacterial resistance and show evidence of skin sensitization. ${ }^{2,33,35}$ For this reason, the relatively lower incidence of adverse reactions of natural products has been intensively investigated. ${ }^{4,33,35}$ Overall, antimicrobial textiles have found uses in hygienic rather than medical field especially due to possible cytotoxic effect and sometimes low effectiveness. ${ }^{4,35}$ Antimicrobial textiles have been designed to address activity against a broad spectrum of microorganisms $\mathrm{s}^{33,35,36}$ but there remain open questions regarding toxicity on human health, which is causing a paradigm change to move on to highly specific agents toward pathogenic bacteria. Likewise, the rising flow of strains resistant to last-resort antibiotics rekindles interest in novel approaches. ${ }^{11,35-37}$

Phage immobilization strategies on organic and inorganic surfaces have been recently reported ${ }^{37-45}$ : while in some cases electrostatic binding showed phage instability and detachment, ${ }^{46}$ covalent attachment offers a much stronger bond. ${ }^{47}$ Still, for antimicrobial surfaces designed to utilize the inherent binding specificity and lytic activity of phage toward the bacterial host, tailed phage should be immobilized through the capsid and filamentous phage with their bacterial-capturing pole exposed. ${ }^{44-46}$

Therefore, in this work we surface-anchored vB Pae-Kakheti25 bacteriophages to develop highly specific antibacterial non-woven textiles/dressings especially - but not limited to - for skin associated infections, as a skin microbiome regulator. Such textiles could also find application as outside catheter dressings to provide adequate fixation and inhibition of bacterial adhesion during catheter lifetime. To authors' knowledge this is the first investigation exploiting phages as antibacterial agents for textiles. The closest approach that one can consider related has been reported by Mao et al., ${ }^{48}$ where a non-lytic filamentous phage (M13) was engineered to express negatively-charged glutamates further glutaraldehyde-crosslinked upon extrusion of fibers and Kevlar coatings with the ability to attract $\mathrm{Ag}^{+}$in a silverization process. The engineered phage was the basis of the fiber and coating but silver was responsible for the antibacterial activity since non-lytic phage was used. Our strategy, in contrary, immobilized lytic phage onto non-woven textile as antibacterial agent.

This study showed that vB Pae-Kakheti25 covalent immobilization on PCL nanofibers with a head-to-tail orientation added antimicrobial properties to the proposed dressing. It presented a microbial reduction of $6 \log$, even after 25 wash cycles, comparatively with the non-modified nanostructure after $2 \mathrm{~h}$ of incubation. Its activity was immediate and $P$. aeruginosa reduction was complete.

On the contrary, when in solution, vB Pae Kakheti25 bacteriophage aggregated and decreased its availability to interact with $P$. aeruginosa.

\section{References}

1. J. Oh, A.L. Byrd, C. Deming, S. Conlan, et al., Biogeography and individuality shape function in the human skin metagenome, Nature 514 (2014) 59-64.

2. C. Lopes, D. Silva, L. Delgado, O. Correia, A. Moreira, Functional textiles for atopic dermatitis: a systematic review and meta-analysis, Pediatr Allergy Immunol 24 (2013) 603-613.

3. J.G. Powers, L.M. Morton, T.J. Phillips, Dressings for chronic wounds, Dermatol Ther 3 (2013) 197-206.

4. J. Ring, A. Alomar, T. Bieber, et al., Guidelines for treatment of atopic eczema (atopic dermatitis) part II, J Eur Acad Dermatol Venereol 26 (2012) 1176-1193.

5. A.M. Misic, S.E. Gardner, E.A. Grice, The wound microbiome: modern approaches to examining the role of microorganisms in impaired chronic wound healing, Adv Wound Care 3 (7) (2014) 502-510.

6. K. Gjødsbøl, J.J. Christensen, T. Karlsmark, et al., Multiple bacterial species reside in chronic wounds: a longitudinal study, Int Wound J 3 (3) (2006) 225-231.

7. F. Nogueira, L. Granadeiro, C. Mouro, I.C. Gouveia, Antimicrobial and antioxidant surface modification toward a new silk-fibroin (SF)-1-cysteine material for skin disease management, App Surf Sci 364 (2016) 552-559.

8. L.M. Weiner, A.K. Webb, B. Limbago, M.A. Dudeck, J. Patel, A.J. Kallen, et al., Antimicrobial-resistant pathogens associated with healthcare-associated infections: summary of data reported to the National Healthcare Safety Network at the Centers for Disease Control and Prevention, 2011-2014, Infect Control Hosp Epidemiol 37 (11) (2016) 1288-1301.

9. K.A. Traugott, K. Echevarria, P. Maxwell, K. Green, J.S. Lewis II, Monotherapy or combination therapy? The Pseudomonas Aeruginosa Conundrum, Pharmacotherapy 31 (6) (2011) 598-608.

10. D.L. Stevens, Infections of the skin, muscle and soft tissues, in: D.L. Kasper, E. Braunwald, A.S. Fauci, et al. (Eds.), Harrison's Principles of Internal Medicine, 16 ed., McGraw-Hill, New York, 2006, p. 740.

11. A. Parisien, B. Allain, J. Zhang, R. Mandeville, C.Q. Lan, Novel alternatives to antibiotics: bacteriophages, bacterial cell wall hydrolases, and antimicrobial peptides, J Appl Microbiol 104 (2008) 1-13.

12. J.S. Soothill, Bacteriophage prevents destruction of skin grafts by Pseudomonas aeruginosa, Burns 20 (3) (1994) 209-211.

13. C.S. McVay, M. Velásquez, J.A. Fralick, Phage therapy of Pseudomonas aeruginosa infection in a mouse burn wound model, Antimicrob Agents Chemother 51 (6) (2007) 1934-1938

14. B.D. Ratner, Biomaterials science: an introduction to materials in medicine, 2nd ed., Elsevier Academic Press, Amsterdam, Boston, 2004854.

15. B.D. Ulery, L.S. Nair, C.T. Laurencin, Biomedical applications of biodegradable polymers, J Polym Sci B 49 (12) (2011) 832-864.

16. Y. Ikada, H. Tsuji, Biodegradable polyesters for medical and ecological applications, Macromol Rapid Commun 21 (3) (2000) 117-132.

17. V. Ilić, Z. Šaponjić, V. Vodnik, R. Molina, S. Dimitrijević, P. Jovančić, et al., Antifungal efficiency of corona pretreated polyester and polyamide fabrics loaded with ag nanoparticles, J Mater Sci 44 (2009) 3983-3990.

18. S.H. Lim, S.M. Hudson, Review of chitosan and its derivatives as antimicrobial agents and their uses as textile chemicals, J Macromol Sci Polym Rev 43 (2) (2003) 223-269.

19. S. Reardon, Antibiotic alternatives rev up bacterial arms race, Nature 521 (2015) 402-403.

20. J. Yang, R. Yan, A. Roy, D. Xu, J. Poisson, Y. Zhang, The I-TASSER suite: protein structure and function prediction, Nat Methods 12 (2015) 7-8.

21. J. Yang, Y. Zhang, I-TASSER server: new development for protein structure and function predictions, Nucleic Acids Res 43 (2015) W174-W181.

22. A. Roy, A. Kucukural, Y. Zhang, I-TASSER: a unified platform for automated protein structure and function prediction, Nat Protoc 5 (2010) 725-738.

23. Y. Zhang, I-TASSER server for protein 3D structure prediction, BMC Bioinformatics 9 (2008) 40.

24. N. Karumidze, J.A. Thomas, N. Kvatadze, M. Goderdzishvili, K.W. Hakala, S.T. Weintraub, et al., Characterization of lytic Pseudomonas aeruginosa bacteriophages via biological properties and genomic sequences, Appl Microbiol Biotechnol 94 (2012) 1609.

25. ISO/TC 194 biological and clinical evaluation of medical devices, in: http://www. iso.org/iso/catalogue detail.htm\%3Fcsnumber $=36406$.

26. G. Socrates, Infrared and Raman characteristic group frequencies: tables and charts, John Wiley \& Sons, Ltd., 2004. 
27. Y. Gao, Y.B. Truong, Y. Zhu, I.L. Kyratzis, Electrospun antibacterial nanofibers: production, activity, and in vivo applications, J Appl Polym Sci 131 (18) (2014) $1-13$.

28. L. Huang, T. Dai, Y. Xuan, G.P. Tegos, M.R. Hamblin, Synergistic combination of chitosan acetate with nanoparticle silver as a topical antimicrobial: efficacy against bacterial burn infections, Antimicrob Agents Chemother 55 (7) (2011) 3432-3438.

29. F. Nogueira, I.C. Gouveia, Amino acid based material for the complementary therapy of decubitus ulcers, J Microbiol Biotechnol 26 (11) (2017).

30. H. Yang, Y. Deng, Preparation and physical properties of superhydrophobic papers, J Colloid Interface Sci 325 (2) (2008) 588-593.

31. J. Langlet, F. Gaboriaud, J.F.L. Duval, C. Gantzer, Aggregation and surface properties of F-specific RNA phages: implication for membrane filtration processes, Water Res 42 (2008) 2769-2777.

32. E. Borenfreund, O. Borrero, In vitro cytotoxicity assays. Potential alternatives to the Draize ocular allergy test, Cell Biol Toxicol 1 (1984) 55-65.

33. L. Windler, M. Height, B. Nowack, Comparative evaluation of antimicrobials for textile applications, Environ Int 53 (2013) 62-73.

34. A. Gauger, S. Fischer, M. Mempel, et al., Efficacy and functionality of silver-coated textiles in patients with atopic eczema, J Eur Acad Dermatol Venereol 20 (2006) 534-541.

35. Y. Gao, R. Cranston, Recent advances in antimicrobial treatments of textiles, Text Res J 78 (1) (2008) 68-72.B.

36. M. Pedrosa, C. Mouro, F. Nogueira, J. Vaz, I.C. Gouveia, Comparison of the antibacterial activity of modified-cotton with Magainin I and LL-37 with potential as wound-dressings, J Appl Polym Sci 131 (21) (2014) 40997, [1-8]

37. J.J. Barra, Bacteriophage adhering to mucus provide a non-host-derived immunity, PNAS 110 (2013) 10771-10776.

38. H. Anany, W. Chen, R. Pelton, M.W. Griffiths, Biocontrol of listeria monocyto-genes and E. coli o157:H7 in meat using phage immobilized on modified cellulose membranes, Appl Environ Microbiol 77 (18) (2011) 6379-6387.
39. R. Cademartiri, H. Anany, I. Gross, R. Bhayani, M. Griffiths, M.A. Brook, Immobilization of bacteriophages on modified silica particles, Biomaterials 31 (2010) 1904-1910.

40. P.J. Yoo, K.T. Nam, J. Qi, S.-K. Lee, J. Park, A.M. Belcher, et al., Spontaneous assembly of viruses on multilayered polymer surfaces, Nat Mater 5 (2006) 234-240.

41. N. Tawil, E. Sacher, R. Mandeville, M. Meunier, Strategies for the immobilization of bacteriophages on gold surfaces monitored by surface Plasmon resonance and surface morphology, J Phys Chem C 117 (13) (2013) 6686-6691.

42. S.K. Arya, A. Singh, R. Naidoo, P. Wu, M.T. McDermott, S. Evoy, Chemically immobilized T4-bacteriophage for specific Escherichia coli detection using surface plasmon resonance, Analyst 136 (3) (2011) 486-492.

43. W. Salalha, J. Kuhn, Y. Dror, E. Zussman, Encapsulation of bacteria and viruses in electrospun nanofibres, Nanotechnology 17 (2006) 4675-4681.

44. A.K. Trillinga, M.M. Harmsenc, V.J.B. Ruigrokd, H. Zuilhofb, J. Beekwildera, The effect of uniform capture molecule orientation on biosensor sensitivity: dependence on analyte properties, Biosens Bioelectron 40 (1) (2013) 219-226.

45. J.-W. Lee, J. Song, M.P. Hwang, K.H. Lee, Nanoscale bacteriophage biosensors beyond vphage display, Int J Nanomedicine 8 (2013) 3917-3925.

46. Z. Hosseinidoust, A. Olsson, N. Tufenkji, Going viral: designing bioactive surfaces with bacteriophage, Colloids Surf B Biointerfaces 124 (2014) 2-16.

47. H.A. Pearson, G.S. Sahukhal, M.O. Elasri, M.W. Urban, Phage-bacterium war on polymeric surfaces: can surface-anchored bacteriophages eliminate microbial infections?, Biomacromolecules 14 (2013) 1257-1261.

48. J.Y. Mao, A.M. Belcher, K.J. Van Vliet, Genetically engineered phage fibers and coatings for antibacterial applications, Adv Funct Mater 20 (2010) 209-214. 